\title{
Analisis Regresi Kuantil B-Splines Monoton Naik pada Hubungan Rata-Rata Lama Sekolah dan Pengeluaran Rumah Tangga Per Kapita di Provinsi Yogyakarta
}

\author{
Yogo Aryo Jatmiko \\ Badan Pusat Statistik, Jakarta \\ yj29289@gmail.com \\ DOI:https://doi.org/10.15642/mantik.2018.4.1.128-136
}

\begin{abstract}
Abstrak
Masalah multidimensional di berbagai negara yang selalu menjadi perhatian pemerintah adalah masalah kemiskinan, tidak terkecuali Indonesia. Kemiskinan sering kali dikaitkan dengan sektor pendidikan dikarenakan fungsi pendidikan sebagai driving force atau daya penggerak transformasi masyarakat untuk memutus rantai kemiskinan. Pola hubungan kemiskinan dan sektor pendidikan dapat dilihat dari hubungan antara tingkat pendidikan (rata-rata lama sekolah) dan tingkat kemiskinan (pengeluaran rumah tangga per kapita). DI Yogyakarta masih merupakan provinsi dengan persentase kemiskinan terbesar di Pulau Jawa walaupun menunjukkan tren penurunan sejak tahun 2007. Penelitian ini bertujuan melihat hubungan antara tingkat pendidikan (rata-rata lama sekolah) dan tingkat kemiskinan (pengeluaran rumah tangga per kapita) di Provinsi DI Yogyakarta tahun 2016. Model yang sesuai untuk menentukan karakteristik rumah tangga adalah regresi kuantil dengan metode $B$-Splines monoton naik yang menghubungkan antara rata-rata lama sekolah dengan pengeluaran rumah tangga per kapita. Hasil estimasi berdasarkan model regresi kuantil dengan $B$-Splines monoton naik diperoleh bahwa rumah tangga dengan tingkat pendidikan terendah dikatakan sebagai rumah tangga sangat miskin jika pengeluaran per kapita sebulan kurang dari 322.205 rupiah dan dikatakan sebagai rumah tangga miskin jika pengeluaran per kapita sebulan antara 322.205 rupiah sampai dengan 426.666 rupiah. Sedangkan, rumah tangga dengan tingkat pendidikan tertinggi dikatakan sebagai rumah tangga sangat miskin jika pengeluaran per kapita sebulan kurang dari 3.410.965 rupiah dan dikatakan sebagai rumah tangga miskin jika pengeluaran per kapita sebulan antara 3.410.965 rupiah sampai dengan 4.676 .718 rupiah.
\end{abstract}

Kata kunci: Regresi Kuantil, B-Splines, Rata-rata Lama Sekolah, Pengeluaran Rumah Tangga per Kapita

\begin{abstract}
The multidimensional problem in various countries that is always become the government's attention is the problem of poverty, Indonesia is no exception. Poverty is often associated with the education sector due to the function of education as a driving force of the transformation of society to break the chain of poverty. The pattern of relations between poverty and the education sector can be seen from the relationship between the level of education (mean years of schooling) and poverty level (per capita household expenditure). DI Yogyakarta is still the province with the largest percentage of poverty on the Java island despite showing a downward trend since 2007. This study aims to look at the relationship between the level of education (mean years of schooling) and poverty level (per capita household expenditure) in DI Yogyakarta Province 2016. The model that is suitable for determining household characteristics is quantile regression with the Increased monotone B-Splines method that links the mean years of schooling and per capita household expenditure. Estimation results based on the quantile regression model with Increased monotone B-Splines method found that households with the lowest education level are said to be very poor households if monthly per capita expenditure is less than 322,205 rupiah and is said to be a poor household if monthly per capita expenditure is between 322,205 rupiah to 426,666 rupiah. Meanwhile, households with the highest level of education are said to be very poor households if monthly per capita expenditure is less than 3,410,965 rupiahs and is said to be a poor household if monthly per capita expenditure is between $3,410,965$ rupiahs up to $4,676,718$ rupiahs.
\end{abstract}

Keywords: Quantile Regression, B-Splines, Mean Years of Schooling, Per Capita Household Expenditure 


\section{JURNAL MATEMATIKA "MANTIK" \\ Oktober 2018. Vol. 04 No. 02}

\section{Pendahuluan}

Kemiskinan dilihat sebagai ketidakmampuan memenuhi kebutuhan dasar makanan dan bukan makanan dari sisi ekonomi yang diukur dari sisi pengeluaran [1]. tingkat kemampuan ekonomi masyarakat dan daya beli masyarakat merupakan cerminan dari tingkat kesejahteraan masyarakat yang ditunjukkan dari pengeluaran untuk kebutuhan konsumsi makanan dan bukan makanan. Kemampuan memenuhi kebutuhan hidup menunjukkan daya beli masyarakat yang tinggi dan selanjutnya berdampak pada meningkatnya kesejahteraan masyarakat.

Masalah multidimensional di berbagai negara yang selalu menjadi perhatian pemerintah adalah masalah kemiskinan, tidak terkecuali Indonesia. Kemiskinan sering kali dikaitkan dengan sektor pendidikan dikarenakan fungsi pendidikan sebagai driving force atau daya penggerak transformasi masyarakat untuk memutus rantai kemiskinan. Pendidikan membantu menurunkan kemiskinan melalui efeknya pada produktivitas tenaga kerja dan melalui jalur manfaat sosial, maka pendidikan menjadi suatu tujuan pembangunan yang penting bagi bangsa [2]. Dengan Pendidikan, peluang kerja menjadi lebih terbuka dan upah yang didapat juga akan lebih tinggi karena pendidikan merupakan sarana untuk memperoleh wawasan, ilmu pengetahuan dan meningkatkan keterampilan.

Pendidikan seseorang merupakan salah satu determinan konsumsi per kapita [3]. Rata-rata lama sekolah yang menunjukkan tingkat pendidikan masyarakat mampu menurunkan tingkat kemiskinan di Indonesia [4]. Masyarakat yang berpendidikan tinggi akan mempunyai keterampilan dan keahlian, sehingga dapat meningkatkan produktivitasnya. Peningkatan produktivitas akan meningkatkan output perusahaan, peningkatan upah pekerja, peningkatan daya beli masyarakat sehingga akan mengurangi kemiskinan.

Pendidikan khususnya peningkatan jumlah tahun belajar merupakan suatu syarat untuk tahap dari pembangunan ekonomi [5]. Semakin tinggi pendidikan seseorang, maka kualitas Sumber Daya Manusia (SDM) juga bertambah baik sehingga produktivitas semakin tinggi. Tentunya semakin tinggi produktivitas, akan meningkatkan penghasilan serta pengeluaran.

Seseorang dengan pendidikan yang lebih tinggi biasanya memiliki akses yang lebih besar untuk mendapatkan pekerjaan dengan bayaran lebih tinggi, dibandingkan dengan individu dengan tingkat pendidikan lebih rendah [6]. Penduduk miskin akan mendapat kesempatan yang lebih baik untuk keluar dari status miskin di masa depan dengan pendidikan yang memadai [7]. Hal ini sejalan dengan yang dikemukakan oleh [8] yaitu kemiskinan akan berkurang apabila investasi pendidikan dilakukan secara merata, termasuk pada masyarakat yang berpenghasilan rendah.

Pada bulan Maret tahun 2016, angka kemiskinan di Indonesia yang dikeluarkan oleh Badan Pusat Statistik (BPS) tercatat sebesar 10,86 persen atau sekitar 28 juta jiwa. Lima puluh empat persen dari jumlah penduduk miskin tersebut berada di Pulau Jawa. DI Yogyakarta masih merupakan provinsi dengan persentase kemiskinan terbesar di Pulau Jawa yaitu sebesar 13,34 persen walaupun menunjukkan tren penurunan sejak tahun 2007. Penelitian ini akan melihat hubungan antara tingkat pendidikan (rata-rata lama sekolah) dan tingkat kemiskinan (pengeluaran per kapita rumah tangga) di Provinsi DI Yogyakarta tahun 2016. Rata-rata lama sekolah adalah Jumlah tahun belajar penduduk usia 15 tahun ke atas yang telah diselesaikan dalam pendidikan formal (tidak termasuk tahun yang mengulang). Untuk level rumah tangga, keterkaitan antara tingkat pendidikan (ratarata lama sekolah) dengan tingkat kemiskinan (pengeluaran rumah tangga) dapat ditunjukkan berdasarkan suatu model regresi. Metode penaksiran model regresi yang diasumsikan mengikuti bentuk persamaan regresi tertentu seperti linier, kuadratik dan yang lainnya disebut regresi parametrik. Akan tetapi peneliti seringkali menemui kesulitan dalam menentukan model hanya melalui sebaran data, sehingga metode yang digunakan adalah regresi nonparametrik. Salah satu teknik penaksiran dalam regresi nonparametrik adalah B- 


\section{JURNAL MATEMATIKA "MANTIK" \\ Oktober 2018. Vol. 04 No. 02}

ISSN: 2527-3159

E-ISSN: 2527-3167

splines. B-splines merupakan teknik penaksiran pada fitting kurva regresi yang memperhitungkan penghalusan.

Metode regresi nonparametrik yang dapat digunakan untuk menduga kurva regresi antara lain dengan menggunakan pendekatan regresi spline. Regresi spline adalah pendekatan ke arah plot data dengan tetap memperhitungkan kemulusan kurva. Spline adalah penduga yang diperoleh dengan meminimumkan penalized least square, yaitu kriteria pendugaan yang menggabungkan goodness-of-fit dengan kemulusan kurva, dimana kedua ukuran ini diatur oleh suatu parameter pemulusan. Pemilihan model optimal (terbaik) menggunakan kriteria Mean Squared Error (MSE) atau Generalized Cross Validation (GCV) dan taksiran parameter menggunakan metode kuadrat terkecil.

\section{Tinjauan Pustaka}

\subsection{Sumber Data}

Data pada penelitian ini menggunakan data yang bersumber dari hasil Survei Sosial Ekonomi Nasional (Susenas) semester I tahun 2016 di Provinsi DI Yogyakarta. Set data yang digunakan merupakan data rumah tangga sebanyak 3.662 rumah tangga. Variabel yang digunakan adalah variabel Pengeluaran Per Kapita sebagai variabel respon dan variabel Rata-rata Lama Sekolah per kapita sebagai variabel prediktor.

\subsection{Variabel Penelitian}

Pengeluaran rumah tangga merupakan biaya yang dikeluarkan untuk dikonsumsi semua anggota rumah tangga selama sebulan, yang terdiri dari konsumsi makanan dan non makanan, tanpa melihat asal barang serta terbatas pada konsumsi untuk keperluan usaha atau yang diberikan kepada pihak lain [1]. Pengeluaran rumah tangga perkapita merupakan pengeluaran rumah tangga dibagi banyaknya anggota rumah dalam suatu rumah tangga atau dengan kata lain rata-rata pengeluaran rumah tangga untuk setiap anggota rumah tangga.

Rata-rata Lama Sekolah (RLS) merupakan jumlah tahun yang digunakan penduduk dalam menjalani pendidikan formal. Penduduk yang dicakup dalam perhitungan RLS adalah penduduk yang berusia 15 tahun ke atas. Rata-rata Lama Sekolah per kapita merupakan rata-rata lama sekolah dari seluruh anggota rumah tangga yang berusia 15 tahun ke atas pada suatu rumah tangga dibagi dengan banyaknya anggota rumah tangga tersebut. RLS dihitung dengan formula sebagai berikut [9]:

$R L S=\frac{1}{P_{15+}} \sum_{i=1}^{P_{15+}} L S_{i}$

di mana:

$\mathrm{P}_{15+}=$ jumlah penduduk usia 15 tahun ke atas $\mathrm{LS}_{\mathrm{i}}=$ lama sekolah penduduk ke-i. =

a. Tidak pernah sekolah $=1$

b. Masih sekolah di SD sampai dengan S1 = konversi ijazah terakhir + kelas terakhir -1

c. Masih sekolah di S2/S3 = konversi ijazah terakhir

d. Tidak bersekolah lagi dan tamat di kelas terakhir $=$ konversi ijazah terakhir

e. Tidak bersekolah lagi dan tidak tamat di kelas terakhir = konversi ijazah terakhir + kelas terakhir

Lama sekolah penduduk berusia 15 tahun ke atas di jenjang pendidikan terakhir yang telah ditamatkan menggunakan konversi berikut (Lihat Tabel 1):

Tabel 1. Konversi Pendidikan tertinggi yang ditamatkan

\begin{tabular}{clc}
\hline \hline No. & \multicolumn{1}{c}{$\begin{array}{c}\text { Pendidikan } \\
\text { tertinggi yang } \\
\text { ditamatkan }\end{array}$} & $\begin{array}{c}\text { Konversi } \\
\text { (Tahun) }\end{array}$ \\
\hline$(1)$ & \multicolumn{1}{c}{$(2)$} & $(3)$ \\
\hline 1. & $\begin{array}{l}\text { Tidak/ belum pernah } \\
\text { sekolah }\end{array}$ & 0 \\
\hline 2. & SD/ sederajat & 6 \\
\hline 3. & SMP/ sederajat & 9 \\
\hline 4. & SMA/ sederajat & 12 \\
\hline 5. & Diploma I & 13 \\
\hline 6. & Diploma II & 14 \\
\hline 7. & Akademi/ Diploma III & 15 \\
\hline 8. & $\begin{array}{l}\text { Diploma IV/ Sarjana } \\
\text { (S1) }\end{array}$ & 16 \\
\hline 9. & Master (S2) & 18 \\
\hline 10. & Doktor (S3) & 21 \\
\hline
\end{tabular}

Sumber: BPS, 2011 


\subsection{Regresi Kuantil Smoothing B-Splines}

Fungsi obyektif kuantil untuk smoothing $B$-Splines dalam bentuk persamaan linier yaitu:

$\min \left\{\widehat{\boldsymbol{W}}^{\boldsymbol{T}} \boldsymbol{u}+\widehat{\boldsymbol{W}}^{\boldsymbol{T}} \boldsymbol{v} \mid \widehat{\boldsymbol{X}} \boldsymbol{\alpha}+\boldsymbol{u}-\boldsymbol{v}=\right.$

$\left.\widehat{\boldsymbol{Y}},\left(\boldsymbol{u}, \boldsymbol{v} \in \mathbb{R}_{+}{ }^{(\boldsymbol{n}+\boldsymbol{u})}\right)\right\}$

Dimana $\mathbf{u} \mathbf{v}$ adalah vektor positif dan negatif bagian dari residual regresi.

$\widehat{\boldsymbol{W}}_{(n+u) \times 1}=\left(\begin{array}{c}\boldsymbol{w} \\ \mathbf{1}_{\boldsymbol{u} \times \mathbf{1}}\end{array}\right)$

dengan $\quad \boldsymbol{w}=\left(\rho_{\tau}\left(z_{1}\right), \ldots, \rho_{\tau}\left(z_{n}\right)\right)^{T}$ adalah vektor penimbang

$\widehat{\boldsymbol{Y}}=\left(\begin{array}{c}\boldsymbol{Y} \\ \mathbf{0}_{\boldsymbol{u} \times \mathbf{1}}\end{array}\right)$

$\widehat{\boldsymbol{Y}}_{(n+u) \times 1}$ merupakan vektor respon pseudo dengan $\boldsymbol{Y}=\left(y_{1}, \ldots, y_{n}\right)^{T}$

$\widehat{\boldsymbol{X}}=\left(\begin{array}{c}\boldsymbol{B} \\ \lambda \boldsymbol{C}\end{array}\right)$

$\widehat{\boldsymbol{X}}_{((n+u) \times m)}$ merupakan matriks design pseudo dengan:

$\boldsymbol{B}_{\boldsymbol{n} \times \boldsymbol{m}}$
$=\left[\begin{array}{cccc}B_{1}\left(x_{1} ; v\right) & B_{2}\left(x_{1} ; v\right) & \ldots & B_{m}\left(x_{1} ; v\right) \\ B_{1}\left(x_{2} ; v\right) & B_{2}\left(x_{2} ; v\right) & \ldots & B_{m}\left(x_{2} ; v\right) \\ \vdots & \vdots & \ddots & \vdots \\ B_{1}\left(x_{n} ; v\right) & B_{2}\left(x_{n} ; v\right) & \ldots & B_{m}\left(x_{n} ; v\right)\end{array}\right]$

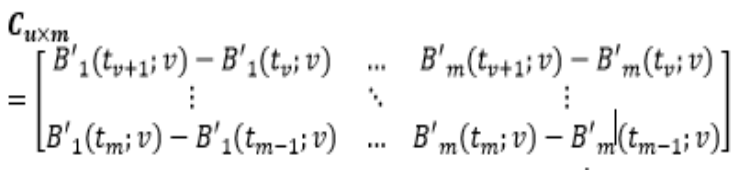

Fungsi obyektifnya: $\widehat{W}^{T} u+\widehat{W}^{T} v$

Fungsi kendalanya: $\widehat{\boldsymbol{X}} \boldsymbol{\alpha}+\boldsymbol{u}-\boldsymbol{v}=\widehat{\boldsymbol{Y}}$

2.4 Pemilihan Parameter Penghalus dan Knot

Kriteria pemilihan parameter penghalus $(\lambda)$ yang paling optimum menggunakan nilai Schawrz Information Criterion (SIC) terkecil [10], dengan formulasi:

$\operatorname{SIC}(\lambda)=\log \left(\frac{1}{n} \sum_{i=1}^{n} \rho_{\tau}\left(y_{i}-\right.\right.$

$\left.\left.\sum_{j=1}^{m} \hat{\alpha}_{j} B_{j}\left(x_{i} ; v\right)\right)\right)+\frac{1}{2} \rho_{\lambda} \frac{\log (n)}{n}$

Dimana $\mathrm{p}_{\lambda}$ merupakan jumlah dari residual nol untuk model yang fit.

Jumlah knot untuk regresi kuantil smoothing B-Splines adalah 20 knot dimana lokasinya dipilih berdasarkan nilai unik dari variabel X [10]. Titik knot ke-u(t $\left.\mathrm{t}_{\mathrm{u}}\right)$ diperoleh dari: $t_{u}=$ kuantil ke -

$\left(\frac{u}{20}\right)$ dari nilai untuk variabel $X ; \quad u=$

$1,2, \ldots, 20$

\subsection{Fungsi Kendala Monoton pada Program Linier untuk Regresi Kuantil}

Penambahan fungsi kendala monoton naik atau turun saat melakukan penaksiran parameter adalah untuk memberikan efek penghalus pada kurva suatu model regresi. Kriteria pengecekan kendala monoton pada fungsi obyektif regresi kuantil pada Smoothing B-Splines yaitu:

$\mathbf{H} \boldsymbol{\alpha}>\mathbf{0}$, untuk fungsi monoton naik

$\mathbf{H} \boldsymbol{\alpha}<\mathbf{0}$, untuk fungsi monoton turun

Dimana:

$\boldsymbol{H}=\left[\begin{array}{ccc}B^{\prime}{ }_{1}\left(t_{v} ; v\right) & \ldots & B^{\prime}{ }_{m}\left(t_{v} ; v\right) \\ \vdots & \ddots & \vdots \\ B^{\prime}{ }_{1}\left(t_{m} ; v\right) & \ldots & B^{\prime}{ }_{m}\left(t_{m-1} ; v\right)\end{array}\right]$

Atau

$\widehat{\boldsymbol{H}} \boldsymbol{x}>0$, untuk fungsi monoton naik

$\widehat{\boldsymbol{H}} \boldsymbol{x}<0$, untuk fungsi monoton turun

Dimana:

$\widehat{H}=\left(\begin{array}{ll}\mathbf{H} \mathbf{0}_{((u+2) \times 2(n+u))} \\ )\end{array}\right.$

\section{Metode Penelitian}

Langkah-langkah dalam penelitian ini mencakup:

1. Membuat scatter plot antar variabel respon dan variabel bebas

2. Melakukan spesifikasi model berdasarkan scatter plot, dalam hal ini digunakan pendekatan fungsi $B$-Splines

3. Pengecekan outlier pada hasil scatter plot dan bila terdapat outlier maka digunakan kuantil. Pengecekan outlier dapat juga dengan melihat distribusi eror dengan rata-rata sebagai ukuran pemusatan data pada fungsi B-Splines

4. Menentukan constrained dari hubungan kedua variabel, apakah monoton baik, monoton turun

5. Menentukan jumlah knot dan parameter smoothing $(\lambda)$. Pada makalah ini digunakan fungsi smoothing $B$-Splines dengan jumlah knot yang digunakan 20 knot, dan parameter smoothing $(\lambda)$ ditentuan berdasarkan nilai Schawrz Information Criterion (SIC) yang terkecil 
6. Menaksir kurva regresi kuantil berdasarkan nilai parameter penghalus $(\lambda)$ yang optimal pada beberapa titik kuantil, yaitu pada $\tau=0,2 ; 0,4 ; 0,6 ; 0,8$

7. Menaksir selang kepercayaan untuk kurva regresi kuantil dengan metode langsung.

\section{Pembahasan Hasil}

Bagian ini akan menjelaskan keterkaitan antara variabel rata-rata lama sekolah dan rata-rata pengeluaran per kapita rumah tangga di Provinsi DI Yogyakarta tahun 2016 yang dimodelkan dengan metode COBS. Alasan digunakan metode COBS adalah plot data (Gambar 1) yang menunjukkan pola yang tidak dapat dispesifikasi secara jelas namun mempunyai kecenderungan meningkat, sehingga akan lebih baik pemodelan dilakukan secara nonparametrik. Adapun yang dimaksud dengan "Constrained" di sini adalah asumsi bahwa hubungan kedua data adalah pola cenderung meningkat yang lebih lanjut disebut dengan "Increase Constrained". Hal ini dapat diartikan bahwa rata-rata pengeluaran rumah tangga per kapita meningkat seiring dengan rata-rata lama sekolah anggota rumah tangga.

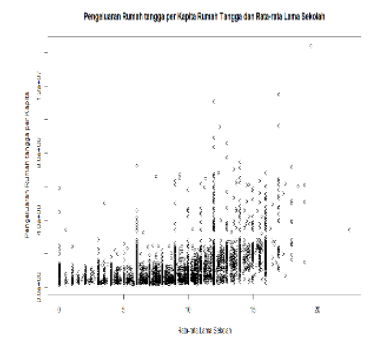

(a)

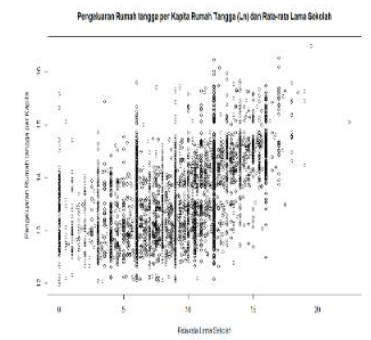

(b)
Gambar 1. Plot Data Pengeluaran Rumah Tangga per Kapita dan Rata-rata Lama Sekolah (a) plot asli (b) plot transformasi

Selain fenomena ketidakberaturannya pola data, fenomena berikutnya adalah terdapatnya data outlier (Gambar 2) dari residual model B-splines yang disajikan dalam regresi mean. Dengan demikian untuk menangkap fenomena keberadaan outlier residual tersebut, maka diterapkan analisis regresi kuantil dalam menaksir parameter model.

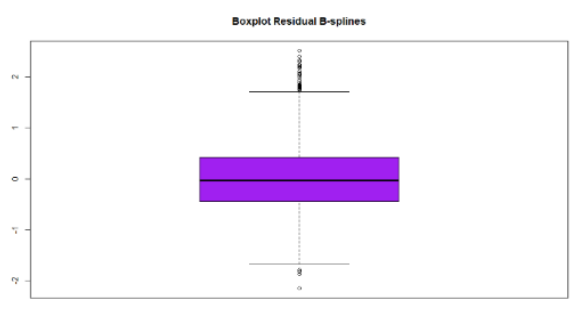

Gambar 2. Boxplot Residual dari Model B-Splines

Lebih lanjut, untuk membagi rumah tangga ke dalam kelompok-kelompok dengan karakteristik yang hampir sama berdasarkan rata-rata lama sekolah anggota rumah tangga dan pengeluaran rumah tangga per kapita maka akan diterapkan empat buah pemodelan regresi kuantil dengan batasan yakni kuantil ke-0,2, kuantil ke-0,4, kuantil ke-0,6 dan kuantil ke-0,8 [11]. Dalam pemodelan regresi kuantil, setiap kuantil memiliki jumlah dan lokasi titik-titik knot (lihat Tabel 2.)

Tabel 2. Titik-titik Knot pada Masingmasing Kuantil

\begin{tabular}{|c|c|c|c|c|c|}
\hline $\begin{array}{c}\text { Titik } \\
\text { ke }\end{array}$ & $\boldsymbol{t}_{\boldsymbol{1}}$ & $\boldsymbol{t}_{\boldsymbol{2}}$ & $\boldsymbol{t}_{\boldsymbol{3}}$ & $\boldsymbol{t}_{\boldsymbol{4}}$ & $\boldsymbol{t}_{\boldsymbol{5}}$ \\
\hline Knot & 0,00 & 2,25 & 3,50 & 4,67 & 5,60 \\
\hline $\begin{array}{c}\text { Titik } \\
\text { ke }\end{array}$ & $\boldsymbol{t}_{\boldsymbol{6}}$ & $\boldsymbol{t}_{\boldsymbol{7}}$ & $\boldsymbol{t}_{\boldsymbol{8}}$ & $\boldsymbol{t}_{\boldsymbol{9}}$ & $\boldsymbol{t}_{\boldsymbol{1 0}}$ \\
\hline Knot & 6,40 & 7,17 & 7,80 & 8,57 & 9,25 \\
\hline $\begin{array}{c}\text { Titik } \\
\text { ke }\end{array}$ & $\boldsymbol{t}_{\boldsymbol{1 1}}$ & $\boldsymbol{t}_{\mathbf{1 2}}$ & $\boldsymbol{t}_{\mathbf{1 3}}$ & $\boldsymbol{t}_{\mathbf{1 4}}$ & $\boldsymbol{t}_{\mathbf{1 5}}$ \\
\hline Knot & 9,86 & 10,57 & 11,33 & 11,83 & 12,67 \\
\hline $\begin{array}{c}\text { Titik } \\
\text { ke }\end{array}$ & $\boldsymbol{t}_{\boldsymbol{1 6}}$ & $\boldsymbol{t}_{\boldsymbol{1 7}}$ & $\boldsymbol{t}_{\mathbf{1 8}}$ & $\boldsymbol{t}_{\boldsymbol{1 9}}$ & $\boldsymbol{t}_{\mathbf{2 0}}$ \\
\hline Knot & 13,50 & 14,33 & 15,20 & 16,67 & 21,00 \\
\hline
\end{tabular}

Sumber: Susenas Maret 2016 BPS, diolah

Tabel 2 menunjukkan titik-titik knot yang dihitung dengan metode kuantil dari nilai unik variabel rata-rata lama sekolah sebanyak 174 nilai. Sementara itu, parameter penghalus kurva $(\lambda)$ optimum pada masingmasing kuantil memiliki nilai yang berbedabeda sebagaimana disajikan pada Gambar 3. 

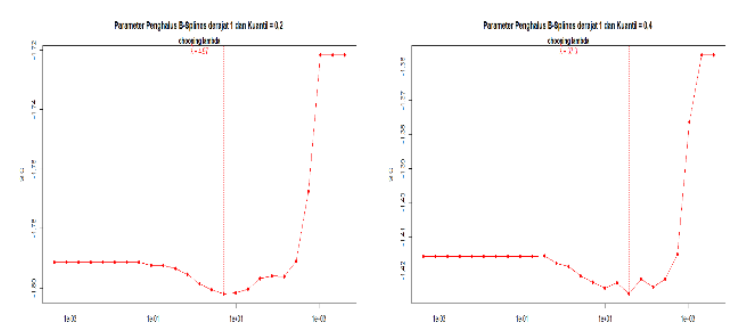

(a) Kuantil $(\tau)=0,2$

(b) Kuantil $(\tau)=0,4$
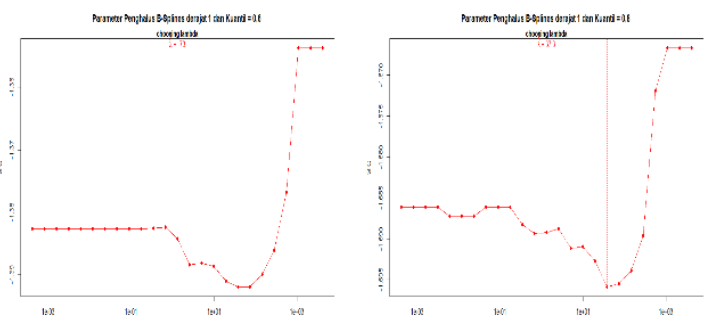

(c) Kuantil $(\tau)=0,6$

(d) Kuantil $(\tau)=0,8$

Gambar 3. Parameter Penghalus $(\lambda)$ optimum berdasarkan nilai SIC terkecil pada masing-masing kuantil.

Gambar 3 (a) menunjukkan pada kuantil ke-0,2 diperoleh parameter penghalus ( $\lambda$ ) optimum sebesar 4.97 dengan SIC minimum sebesar -1,8019. Gambar 3 (b) menunjukkan pada kuantil ke-0,4 diperoleh parameter penghalus $(\lambda)$ optimum sebesar 37.3 dengan SIC minimum sebesar -1,4268. Gambar 3 (c) menunjukkan pada kuantil ke0,6 diperoleh parameter penghalus $(\lambda)$ optimum sebesar 73 dengan SIC minimum sebesar -1,3919. Gambar 3 (d) menunjukkan pada kuantil ke-0,8 diperoleh parameter penghalus $(\lambda)$ optimum sebesar 37,3 dengan SIC minimum sebesar -1,6959.

Berbekal titik-titik knot dan parameter penghalus $(\lambda)$ optimum yang telah diperoleh pada masing-masing kuantil, maka kurva regresi kuantil yang berbasis metode COBS untuk smoothing B-Splines linier dengan asumsi monoton naik (Increase Constrain) disajikan pada Gambar 4.

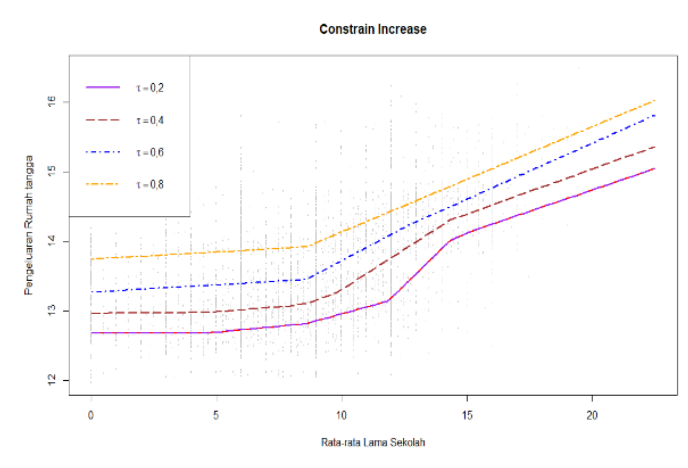

Gambar 4. Kurva Regresi Kuantil dengan COBS

Gambar 4 menunjukkan estimasi pengeluaran rumah tangga per kapita berdasarkan rata-rata lama sekolah anggota rumah tangga pada kuantil ke-0,2, kuantil ke0,4, kuantil ke-0,6 dan kuantil ke-0,8. Pada kuantil ke-0,6 dan kuantil ke-0,8 terlihat bahwa pada rata-rata lama sekolah sekitar tujuh tahun ke atas secara drastis meningkatkan pengeluaran per kapita. Estimasi pengeluaran rumah tangga per kapita tersebut diperoleh dari model regresi kuantil yang memiliki koefisien ( $\alpha)$ sebagaimana disajikan pada Tabel 3.

Tabel 3. Koefisien Regresi Kuantil BSplines Linier pada Kuantil ke-0,2, ke-0,4, ke-0,6 dan ke- 0,8

\begin{tabular}{ccccc}
\hline \hline \multirow{2}{*}{$\begin{array}{c}\text { Knot } \\
\text { ke- } i\left(t_{i}\right)\end{array}$} & $\tau=0,2$ & $\tau=0,4$ & $\tau=0,6$ & $\tau=0,8$ \\
\hline$(1)$ & $(2)$ & $(3)$ & $(4)$ & $(5)$ \\
\hline 1 & 12,6829 & 12,9638 & 13,2692 & 13,7414 \\
\hline 2 & 12,6829 & 12,9708 & 13,3160 & 13,7878 \\
\hline 3 & 12,6829 & 12,9747 & 13,3421 & 13,8135 \\
\hline 4 & 12,6829 & 12,9783 & 13,3664 & 13,8376 \\
\hline 5 & 12,7152 & 13,0045 & 13,3858 & 13,8568 \\
\hline 6 & 12,7429 & 13,0271 & 13,4024 & 13,8733 \\
\hline 7 & 12,7695 & 13,0487 & 13,4184 & 13,8892 \\
\hline 8 & 12,7914 & 13,0665 & 13,4316 & 13,9022 \\
\hline 9 & 12,8180 & 13,1050 & 13,4485 & 13,9180 \\
\hline 10 & 12,8850 & 13,1949 & 13,5784 & 14,0208 \\
\hline 11 & 12,9450 & 13,2755 & 13,6948 & 14,1130 \\
\hline 12 & 13,0149 & 13,4391 & 13,8304 & 14,2203 \\
\hline 13 & 13,0897 & 13,6144 & 13,9755 & 14,3352 \\
\hline 14 & 13,1389 & 13,7296 & 14,0710 & 14,4107 \\
\hline 15 & 13,4338 & 13,9233 & 14,2314 & 14,5377 \\
\hline 16 & 13,7252 & 14,1147 & 14,3645 & 14,6631 \\
\hline 17 & 14,0166 & 14,3060 & 14,4976 & 14,7885 \\
\hline 18 & 14,1478 & 14,4180 & 14,6372 & 14,9200 \\
\hline 19 & 14,3279 & 14,6073 & 14,8730 & 15,1422 \\
\hline & & & &
\end{tabular}




\begin{tabular}{lllll}
\hline 20 & 15,0425 & 15,3581 & 15,8082 & 16,0233 \\
\hline \hline
\end{tabular}

Sumber: Susenas Maret 2016 BPS, diolah

Tabel 3 menunjukkan nilai koefisien pada masing-masing kuantil yang cenderung naik, hal inilah yang menjadikan kurva regresi kuantil pada Gambar 4 cenderung naik. Dengan demikian adanya hubungan antara rata-rata lama sekolah anggota rumah tangga dan pengeluaran rumah tangga per kapita yang cenderung meningkat sejalan dengan asumsi (Increase Constrain).

Selanjutnya akan dihitung estimasi pengeluaran per kapita pada beberapa ratarata lama sekolah seseorang yang menunjukkan jenjang pendidikan tertentu. Beberapa jenjang pendidikan yang digunakan dalam estimasi pengeluaran per kapita tersebut meliputi 0 tahun (tidak/belum pernah sekolah), 6 tahun (SD/sederajat), 9 tahun (SMP/sederajat), 12 tahun (SMA/sederajat), 13 tahun (Diploma I/II), 15 tahun (Akademi/Diploma III), 16 tahun (Diploma IV/Sarjana S1), 18 tahun (Master/Sarjana S2) dan 21 tahun (Sarjana S3).

Tabel 4 menginformasikan bahwa pada kuantil ke-0,2 anggota rumah tangga dengan rata-rata lama sekolah 0 tahun memiliki pengeluaran per kapita sebesar 322.205 rupiah, sementara itu anggota rumah tangga dengan rata-rata lama sekolah 6 tahun memiliki pengeluaran per kapita 337.396 rupiah, demikian seterusnya hingga anggota rumah tangga dengan rata-rata lama sekolah 21 tahun memiliki pengeluaran per kapita sebesar 3.410.965 rupiah. Pada kuantil ke-0,4 menunjukkan anggota yang tidak/belum pernah sekolah memiliki pengeluaran per kapita sebesar 426.666 rupiah, anggota rumah tangga dengan rata-rata lama sekolah 6 tahun akan memiliki pengeluaran per kapita sebesar 449.455 rupiah, demikian seterusnya hingga pada anggota rumah tangga dengan rata-rata lama sekolah 21 tahun memiliki pengeluaran per kapita sebesar 4.676.718 rupiah. Pada kuantil ke-0,6 menunjukkan anggota yang tidak/belum pernah sekolah memiliki pengeluaran per kapita sebesar 579.083 rupiah, anggota rumah tangga dengan rata-rata lama sekolah 6 tahun akan memiliki pengeluaran per kapita sebesar 656.112 rupiah, demikian seterusnya hingga pada anggota rumah tangga dengan rata-rata lama sekolah 21 tahun memiliki pengeluaran per kapita sebesar 7.334.840 rupiah. Pada kuantil ke-0,8 menunjukkan anggota yang tidak/belum pernah sekolah memiliki pengeluaran per kapita sebesar 928.555 rupiah, anggota rumah tangga dengan ratarata lama sekolah 6 tahun akan memiliki pengeluaran per kapita sebesar 1.050.794 rupiah, demikian seterusnya hingga pada anggota rumah tangga dengan rata-rata lama sekolah 21 tahun memiliki pengeluaran per kapita sebesar 9.095.333 rupiah (lihat Tabel 4).

Tabel 4. Nilai Estimasi Pengeluaran Rumah Tangga berdasarkan Rata-rata Lama Sekolah pada Kuantil ke-0,2, ke-0,4, ke-0,6 dan ke-0,8

\begin{tabular}{crrrr}
\hline \hline Rata- & \multicolumn{5}{c}{ Estimasi Pengeluaran Per Kapita (Rp) } \\
\cline { 2 - 5 } rata \\
$\begin{array}{c}\text { Lama } \\
\text { Sekolah } \\
\text { (Tahun) }\end{array}$ & $\tau=0,2$ & $\tau=0,4$ & $\tau=0,6$ & $\tau=0,8$ \\
\hline$(1)$ & $(2)$ & $(3)$ & $(4)$ & $(5)$ \\
\hline 0 & $322.205,3$ & $426.665,6$ & $579.082,8$ & $928.554,8$ \\
\hline 6 & $337.395,9$ & $449.455,0$ & $656.112,0$ & $1.050 .794,5$ \\
\hline 9 & $384.754,1$ & $520.132,3$ & $752.112,9$ & $1.182 .351,8$ \\
\hline 12 & $539.621,9$ & $954.385,9$ & $1.333 .644,9$ & $1.860 .593,8$ \\
\hline 13 & $766.577,1$ & $1.201 .850,7$ & $1.598 .030,4$ & $2.164 .145,8$ \\
\hline 15 & $1.352 .709,0$ & $1.780 .285,7$ & $2.202 .482,8$ & $2.927 .901,4$ \\
\hline 16 & $1.537 .741,4$ & $2.024 .960,6$ & $2.585 .688,9$ & $3.405 .582,4$ \\
\hline 18 & $1.964 .911,5$ & $2.619 .812,9$ & $3.563 .721,7$ & $4.607 .457,1$ \\
\hline 21 & $3.410 .964,9$ & $4.676 .717,7$ & $7.334 .840,2$ & $9.095 .332,7$ \\
\hline \hline
\end{tabular}

Sumber: Susenas Maret 2016 BPS, diolah

Berdasarkan estimasi pengeluaran per kapita pada masing-masing kuantil akan ditentukan klasifikasi rumah tangga berdasarkan rata-rata lama sekolah dan pengeluaran per kapita rumah tangga di Provinsi DI Yogyakarta tahun 2016. Adapun kriteria klasifikasi pada setiap rata-rata lama sekolah adalah sebagai berikut:

Rumah tangga dengan rata-rata lama sekolah anggota rumah tangganya 0 tahun diklasifikasikan:

a) "sangat miskin" jika pengeluaran per kapitanya kurang dari 322.205,27 rupiah;

b) "miskin" jika pengeluaran per kapitanya antara 322.205,27 sampai dengan 426.665,57 rupiah;

c) "menengah" jika pengeluaran per kapitanya antara 426.665,57 sampai dengan 579.082,84 rupiah; 
d) "kaya" jika pengeluaran per kapitanya antara 579.082,84 sampai dengan 928.554,80 rupiah; dan

e) "sangat kaya" jika pengeluaran per kapitanya di atas 928.554,80 rupiah;

Sedangkan rumah tangga dengan ratarata lama sekolah anggota rumah tangganya 21 tahun diklasifikasikan:

a) "sangat miskin" jika pengeluaran per kapitanya kurang dari 3.410.964,9 rupiah;

b) "miskin" jika pengeluaran per kapitanya antara 3.410.964,9 sampai dengan 4.676.717,7 rupiah;

c) "menengah" jika pengeluaran per kapitanya antara 4.676.717,7 sampai dengan 7.334.840,2 rupiah;

d) "kaya" jika pengeluaran per kapitanya antara 7.334.840,2 sampai dengan 9.095.332,7 rupiah; dan

e) "sangat kaya" jika pengeluaran per kapitanya di atas 9.095.332,7 rupiah;

Dengan menggunakan model regresi kuantil dapat ditentukan nilai selang interval pengeluaran per kapita pada masing-masing kuantil yang disajikan pada Gambar 5.

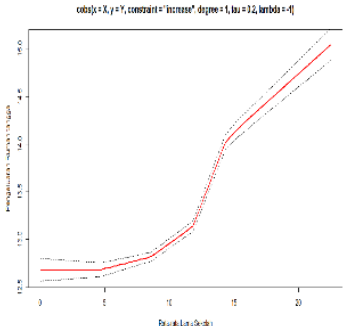

(a) Kuantil $(\tau)=0,2$

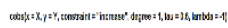

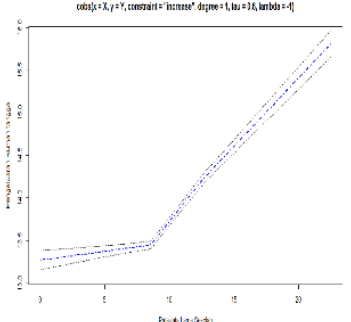

(c) Kuantil $(\tau)=0,6$

Gambar 5. Selang in dengan COBS untuk masing-masing kuantil:

(a) kuantil ke-0,2 ; (b) kuantil ke-0,4 ; (c) kuantil ke- 0,6 ; (d) kuantil ke- 0,8
Gambar 5 menunjukkan nilai selang interval pengeluaran per kapita dan rata-rata lama sekolah pada taraf signifikansi 95 persen. Secara umum hubungan rata-rata lama sekolah dan pengeluaran rumah tangga per kapita pada masing-masing kuantil menunjukkan hubungan yang searah, artinya semakin tinggi rata-rata lama sekolah seseorang maka pengeluaran per kapita juga akan semakin tinggi.

Seluruh batas bawah dan batas atas menunjukkan kecenderungan meningkat baik dari rata-rata lama sekolah paling rendah (0 tahun) ke rata-rata lama sekolah yang paling tinggi (21 tahun) maupun kecenderungan meningkat dari kuantil ke-0,2 ke kuantil ke0,8 . Hal ini menunjukkan adanya asumsi Increase Constrained pada data rata-rata lama sekolah yang secara signifikan berpengaruh terhadap peningkatan pengeluaran per kapita rumah tangga.

\section{Kesimpulan}

Beberapa kesimpulan yang dapat diambil dari penelitian ini adalah sebagai berikut:

1) Model regresi kuantil yang terbentuk dengan metode COBS terbagi menjadi empat yaitu kuantil ke-0,2, kuantil ke0,4, kuantil ke-0,6 dan kuantil ke-0,8. Seluruh koefisien pada model regresi menunjukkan kecenderungan yang meningkat baik dari knot terkecil ke knot terbesar dan dari kuantil terkecil hingga kuantil terbesar;

2) Estimasi pengeluaran rumah tangga per kapita yang diperoleh dari model regresi kuantil dengan metode COBS menunjukkan kecenderungan peningkatan baik dari knot terkecil ke knot terbesar dan dari kuantil terkecil hingga kuantil terbesar;

3) Berdasarkan nilai estimasi pengeluaran rumah tangga per kapita dan rata-rata lama sekolah dapat ditentukan klasifikasi rumah tangga menurut level ekonomi sangat miskin, miskin, menengah, kaya dan sangat kaya. Berdasarkan klasifikasi yang terbentuk dapat dikatakan bahwa semakin tinggi rata-rata lama sekolah anggota rumah tangga akan semakin 
berpengaruh meningkatkan pengeluaran per kapita.

\section{Referensi}

[1] BPS. Data dan Informasi Kemiskinan Kabupaten Kota Tahun 2016. Jakarta: BPS (2016)

[2] World Bank. Era Baru dalam Pengentasan Kemiskinan di Indonesia (Ikhtisar). The World Bank Office Jakarta: Jakarta (2005)

[3] Andersson, Magnus \& Engvall, Anders \& Kokko, Ari. (2006). Determinants Of Poverty In Lao Pdr. The European Institute of Japanese Studies, EIJS Working Paper Series.

[4] Suparno. Analisis Pertumbuhan Ekonomi dan Pengurangan Kemiskinan: Studi Pro Poor Growth Policy di Indonesia. Tesis. S2 IE-IPB. Bogor (2010)

[5] Frankel, J.A. (1997) Regional Trading Blocs in the World Economic System. Institute for International Economics, Washington DC. (1997). http://dx.doi.org/10.7208/chicago/9780226 260228.001.0001

[6] Bureau of Labor Statistics. A Profile of The Working Poor 2011. Federal Publication.
Washington, DC: Cornell University ILR School. (2013)

[7] Wirawan, I. M. T, Arka, S. Analisis Pengaruh Pendidikan, PDRB per Kapita, dan Tingkat Pengangguran terhadap Jumlah Penduduk Miskin Provinsi Bali. E-Jurnal EP Unud, Vol. 4, No. 5, Mei (2015) (pp. 348 - 607)

[8] Mankiw, N. G., Romer, D., Weil, D.N. A Contribution to the Empirics of Economic Growth. The Quarterly Journal of Economics, (1992) pp. 407-437. DOI: $10.3386 / \mathrm{w} 3541$

[9] BPS. Rata-rata Lama Sekolah (MYS). https:// sirusa.bps.go.id/ index.php? r= indicator / view\&id=11. Diakses pada 9 Oktober 2018.

[10] He, X dan Ng, P. COBS: Quatitatively Constraint Smoothing via Linier Programming. Computational Statistics. (1999) 14:315-337

[11] Hudoyo, L.P. Pemodelan Hubungan Antara Rata-rata Lama Sekolah dan Pengeluaran Rumah Tangga Menggunakan Constrained B-Splines (COBS) pada Regresi Kuantil. (2017). Tesis: Universitas Padjajaran 